\title{
ESTIMATION OF Na GENE FREQUENCY ON NATIVE CHICKEN POPULATION AND ITS EFFECT ON HATCHABILITY PERFORMANCE
}

\author{
J. Setianto, Warnoto and T. Triadi \\ Department of Animal Science. Faculty of Agriculture, Bengkulu University \\ Jl. Raya Kandang Limun, Bengkulu - Indonesia. \\ Corresponding E-mail: jsetbkl@yahoo.com
}

Received July 28, 2009; Accepted November 10, 2009

\begin{abstract}
The objective of this research was to estimate the $\mathrm{Na}$ gene frequency of the native chicken population and its effect on hatchability performance. The research used Native Chickens with Nakedneck phenotype and Normal-feathered Native Chicken, consisted of 16 cocks and 48 hens as the parent. They were put in 4 breeding groups : 1) Breeding group of Legund Cock with Legund Hen (LL); 2) Legund Cock with Normal-feathered Native Hen (LN); 3) Normal-feathered Native Cock with Legund Hen (NL); 4) Normal-feathered Native Cock with Normal-feathered Native Hen (NN). Each group consisted of 4 replications and each replication consisted of 1 Cock with 3 Hens. Completely Randomized Design (CRD) were used to analysis the fertility, hatchability and embryo mortality. Hardy-Weinberg's Law of Gene equilibrium method was used to find out the spreading estimation of $\mathrm{Na}$ and na gene in whole offspring population. Experimental result showed that the breeding groups had no influence $(\mathrm{P}>0.05)$ on egg fertility, hatchability and embryo mortality. The phenotypes of the offspring of the breeding groups were not deviate from the Mendel's law. The estimation of the Na gene frequency was $19.7 \%$.
\end{abstract}

Keywords : naked-neck. Na gene. fertility. hatchability and embryo mortality

\section{INTRODUCTION}

Native Chicken is one of the high potential poultry as layer and broiler so that it can help to increase the income and to fulfill the need of animal proteins for local people. Native chicken is often named after its original area, specific trait and feather color (Sarwono, 2003). Through out Indonesia. it was known as Cemani Chicken, Kedu Chicken. Pelung Chicken. Burgo Chicken, Nunukan Chicken., etc.

One of the phenotype varieties of native Chicken was characterized by no feather on its neck that called Legund / naked-neck (Warnoto, 1993). Legund appearance was caused by the $\mathrm{Na}$ gene in homozygote condition $(\mathrm{NaNa})$ or in heterozygote condition (Nana). Sidadolog (1991) clarified that in homozygote condition $(\mathrm{NaNa})$ could be marked by a widening on some part of the body where feather was not grown (bald) until chest, thigh and the surrounding area. A further explanation showed that in heterozygote condition (Nana) the part of the body that was bald was only the neck. It has been reported that the part of the body where feather was not grown in heterozygote condition (Nana) was 20\%-30\%. In the homozygote condition (NaNa) it was $40 \%$ compare to the body's surface where feathers in normal condition (Cahaner et al., 1993; Mazzi et al. 2003; Islam and Nishibori, 2009)

$\mathrm{Na}$ gene on Legund cock and Legund hen indirectly affected a better growth than Normalfeathered Native Chickens starting from the age of 6 weeks and had the ability to consume the feed more efficiently than Normal-feathered Native Chickens (Warnoto, 1993). On the village breeding condition, local Legund Chicken was better than local Normal-feathered Native Chicken in egg production performance, flesh as a broiler, and a resistance towards diseases (Barua et al., 1998). Legund Chicken was better at reistance to diseases than Normal-feathered Native Chicken (Islam, 2006).

Legund Chicken had a good tolerant against hot environment (Horst dan Mathur. 1989). With the better balanced body temperature than Normal-feathered Native Chicken, the $\mathrm{Na}$ gene will indirectly affect the production trait. Therefore, it will have a better egg production and good life capability (Khatun et al., 2005; El-Safty et al., 2006; Galal et al., 2007).

A research about the estimation of $\mathrm{Na}$ gene 
frequency is mostly needed to reveal the causes of the small amount of Legund Chicken population on Native Chicken population. The objective of this research was to estimate the $\mathrm{Na}$ gene within Native Chicken population and its effect towards fertility. hatchability. and embryo mortality. A concentrate with the composition of 40:30:30.

The eggs from each postal house was collected every day and identified by its breeding group. The eggs were hatched in every 7 days after the collection day in an incubator. Inside the incubator. these eggs were separated according to

Table 1. Chi-square Test for Offspring Chick Phenotype

\begin{tabular}{lcccccc}
\hline & \multirow{2}{*}{$\begin{array}{c}\text { Number } \\
\text { BreedingGroup }\end{array}$} & \multicolumn{4}{c}{ The phenotype of hatched chicks } \\
\cline { 3 - 6 } & chicks & & Observation $(\mathrm{O})$ & Expectation $(\mathrm{E})$ & \multirow{2}{*}{$\chi^{2}$} \\
\cline { 3 - 6 } & & Legund & Normal & Legund & Normal & \\
\hline LL/NanaxNana & 44 & 30 & 14 & 29.3 & 14.7 & 0.05 \\
LN/Nanaxnana & 49 & 21 & 28 & 24.5 & 24.5 & 1 \\
NL/nanaxNana & 66 & 26 & 40 & 33 & 33 & 2.96 \\
NN/nanaxnana & 36 & 0 & 36 & 0 & 36 & 0 \\
\hline Population & 195 & 77 & 118 & 86.8 & 108.2 & 1.99 \\
\hline
\end{tabular}

Probability rate less than $0.05 . \chi^{2}<\chi^{2}$ table $0.05: 1=3.841$

dominant naked-neck trait (Na gene) could be inherited. so the $\mathrm{Na}$ gene frequency within the population could be estimated.

\section{MATERIALS AND METHODS}

Housing used were 16 houses unit with the size of $125 \mathrm{~cm} \times 130 \mathrm{~cm}$. each house provided with a place to feed. to drink and egg nest. Before the house were used. all of them were sprayed pesticides.

The chosen cocks and hens (aged 8 month until 10 month) were healthy and had no physical defects used as the parents. The parents consisted of 8 Legund Cocks with Nana genotype, 8 Normal-feathered Native Cocks with nana genotype, 24 Legund Hens and 24 Normalfeathered Native Hens. These parents were grouped into 16 coops unit. Each group consisted of 1 cock and 3 hens. The four breeding groups were established consisting of : 1) Breeding group of Legund Cock with Legund Hen (LL/NanaxNana); 2) Legund Cock with Normalfeathered Native Hen (LN/Nanaxnana); 3) Normal-feathered Native Cock with Legund Hen (NL/nanaxNana); 4) Normal-feathered Native Cock with Normal-feathered Native Hen (NN/nanaxnana). Each breeding group consisted of 4 house units.

The parents were raised for a month to be given the chance to breed. The parents were raised intensively by adlibitum feeding. Feeds that were given were corn. mixture of rice and bran. and their breeding groups with gauze wire as its borders for each egg $(6 \mathrm{~cm} \times 5 \mathrm{~cm})$. This bordering started from the $18^{\text {th }}$ day of hatching. Then fertility, hatchability and embryo mortality were recorded. Hatchability was the fertile egg percentage. Embryo mortality (eggs that were not hatch) was estimated after candling I on the $7^{\text {th }}$ day, candling II on the $16^{\text {th }}$ day and at the end hatching.

Completely Randomized Design (CRD) were used to analysis the fertility, hatchability and embryo mortality. The model used was stated below:

$$
Y_{i j}=\mu+\mathrm{p}_{\mathrm{i}}+\varepsilon_{i j}
$$

where $Y_{i j}$ : Observation on $\mathrm{i}^{\text {th }}$ treatment of the $\mathrm{j}^{\text {th }}$ replication; $\mu$ : overall mean; $\mathbf{p}_{\mathrm{i}}: \mathrm{i}^{\text {th }}$ treatment effect and $\mathcal{E}_{i j}$ : experimental error on $\mathrm{i}^{\text {th }}$ treatment of the $\mathrm{j}^{\text {th }}$ replication.

Chi-square test method was used to find out the spreading phenotype of Legund and normalfeathered data analysis (Gaspersz, 1991):

$$
\chi^{2}=\sum \frac{(0-E)^{2}}{E}
$$

where $\chi^{2}=$ Chi-square test. $E=$ Expected Value (Legund and normal-feathered), $\mathrm{O}=$ Observed Value.

Hardy-Weinberg's Law of Gene equilibrium method was used to find out the spreading estimation of $\mathrm{Na}$ and na gene in whole offspring population as explained by Warwick et al. (1983) as: $\mathrm{p}^{2}+2 \mathrm{pq}+\mathrm{q}^{2}=1$, where $\mathrm{p}^{2}=$ individual with $\mathrm{NaNa}$ genotype, $2 \mathrm{pq}=$ individual with Nana 
Tabel 2. Estimation of Na gene Frequency on the Offspring Chick Population.

\begin{tabular}{cccccccc}
\hline $\begin{array}{c}\text { Breeding } \\
\text { Group }\end{array}$ & \multicolumn{3}{c}{ Offspring Genotype } & Total & $\begin{array}{c}\Sigma \\
\text { Gene } \\
\text { (locus) }\end{array}$ & $\begin{array}{c}\Sigma \\
\text { Gene } \\
\text { Na }\end{array}$ & $\begin{array}{c}\text { Gene } \\
\text { Frequency } \\
\text { Na (\%) }\end{array}$ \\
\cline { 2 - 4 } & NaNa & Nana & nana & & & & \\
\hline LL/NanaxNana & 0 & 30 & 14 & 44 & 88 & 30 & 34.1 \\
LN/Nanaxnana & 0 & 21 & 28 & 49 & 98 & 21 & 21.4 \\
NL/nanaxNana & 0 & 26 & 40 & 66 & 132 & 26 & 19.7 \\
NN/nanaxnana & 0 & 0 & 36 & 36 & 72 & 0 & 0 \\
\hline Total & 0 & 77 & 118 & 195 & 390 & 77 & 19.7 \\
\hline
\end{tabular}

heterozygote genotype. and $\mathrm{q}^{2}=$ individual with nana homozygote genotype.

\section{RESULT AND DISCUSSION}

\section{Chick's Phenotype Chi-Square Test}

Chick's phenotype test was based on the phenotype of the hatched chicks from each parent's breeding group and the population of the fours. The research objective was to know the parent's $\mathrm{Na}$ and na genes inherited to the offspring accordingly to Mendel's gene segregation law.

Based on Mendel's theory of domination, breeding between dihybrid individuals with one of the dominant gene of the allele will result offspring with phenotype of 3:1. This will be fulfilled if there were no other factors such as sexlinkage, epistasis and others including lethal or semi-lethal.

$\mathrm{Na}$ gene in homozygote condition causes the death of the embryo (lethal). It was reported that hatched chicks with NaNa homozygote genotype are rarely found. Warnoto (1993) found only 3 chicks from 600 other hatched chicks that having phenotype with nearly-bold body surface traits. Sidadolog (1991) clarified that $\mathrm{Na}$ gene is semi lethal. In homozygote condition,it can cause death. and the chicks rarely reach the age of sexual maturity.
The chi-square based on all Legund Chicken phenotype including parent and offspring with heterozygote (Nana) genotype is shown in Table 1. Phenotypic comparison of bald phenotype and normal-feathered inheritance follow Mendel's theory of dominance.

The chi-square test showed that in each breeding group and in a whole population of hatched chicks showed smaller rate compared to the border limit of rejection $\chi^{2}$ table $0.05: 1=$ 3.841. Based on $\chi^{2}$ obtained rate, it is shown that the breeding group of LL had smaller phenotype comparison deviation of 0.05 or $5 \%$ from the expected phenotype comparison from Mendel's law. Each breeding group of LN and NL had a deviation of $1.00(10 \%)$ and $2.96(29.6 \%)$, while $100 \%$ breeding group of $\mathrm{NN}$ observation result was appropriate with the expected rate or $0 \%$ deviation.

Estimated result of $\chi^{2}$ showed that the death estimation of embryo with $\mathrm{NaNa}$ homozygote genotype and hatched Legund chick that reach the age of sexual maturity with Nana heterozygote genotype were more acceptable. Besides. if individual $\mathrm{NaNa}$ homozygote chick $=0$ and included in the analysis inside the $\chi^{2}$ estimation rate the deviation probability of chick phenotype comparison of the breeding group of LL offspring were very big so the rate of $\chi^{2}>\chi^{2}$ table in on the

Tabel 3. Average Percentage of Fertility, Hatchability and Embryo Mortality in Each Breeding Group.

\begin{tabular}{lccc}
\hline \multicolumn{1}{c}{ Breeding Group } & $\begin{array}{c}\text { Fertility } \\
(\boldsymbol{\%})\end{array}$ & $\begin{array}{c}\text { Hatchability } \\
(\boldsymbol{\%})\end{array}$ & $\begin{array}{c}\text { Embryo Mortality } \\
(\%)\end{array}$ \\
\hline LL/NanaxNana & 81.75 & 45.08 & 54.92 \\
LN/Nanaxnana & 79.61 & 49.18 & 50.83 \\
NL/nanaxNana & 86.38 & 52.24 & 47.76 \\
NN/nanaxnana & 84.12 & 39.00 & 60.66 \\
\hline Population Average & 82.96 & 46.37 & 53.54 \\
\hline Significance & $\mathrm{ns}$ & $\mathrm{ns}$ & $\mathrm{ns}$ \\
\hline
\end{tabular}


acceptance border limit of observation result.

\section{Estimation of Na gene Frequency}

Estimation of $\mathrm{Na}$ gene frequency can be done inside of population where cocks and hens can randomly bred. Crossbreeding of the parent's groups (LL. LN. NL. NN) can be represent a random breed between Legund Chicken with Normal-feathered Native Chicken inside of population, so that Estimation of $\mathrm{Na}$ gene frequency can be estimated. The estimation results of $\mathrm{Na}$ gene frequency can be seen in Table 2 .

Gene frequency similarity in equilibrium according to Hardy-Weinberg is $\mathrm{p}^{2}+2 \mathrm{pq}+\mathrm{q}^{2}=1$. in the condition of dominant homozygote $(\mathrm{NaNa})$ $=p^{2}$, heterozygote $($ Nana $)=2 p q$ and recessive homozygote $($ nana $)=\mathrm{q}^{2}$.

The result obtained from the breeding group of LL, LN, NL and NN indicated that the $\mathrm{Na}$ gene estimation frequency was continuously decreased. Referring to the parents within the breeding group of LN, the Na gene frequency is higher than breeding group of NL. Estimate the result of $\mathrm{Na}$ gene frequency of LN breeding group was 0.017 higher compared to the NL breeding group. It shows that parent's sex influencing the inheritance of $\mathrm{Na}$ gene traits.

A whole offspring of breeding group of LL, $\mathrm{LN}, \mathrm{NL}$ and $\mathrm{NN}$ obtained the data of $\mathrm{NaNa}$ genotype $=0$, Nana $=77$ chickens, and nana $=$ 118 chickens. According to these data, it could be estimated that the individual with $\mathrm{NaNa}$, Nana and nana genotypes in the whole population respectively were $0 \%, 0.395 \%$ and $0.605 \%$, respectively. It means that homozygote $(\mathrm{NaNa})$ had no offspring or died because of lethal gene, meanwhile Nana and nana has $39.5 \%$ and $60.5 \%$, respectively The estimation of $\mathrm{Na}$ frequency gave result inside the Native Chicken as big as $19.7 \%$. There will be $19.7 \% \mathrm{Na}$ gene in some areas if there are some Legund Chicken cocks or hens that randomly breed with the Normal-feathered Native Chicken in that areas.

\section{Hatching Performance}

Hatching performance (fertility. hatchability. and embryo mortality) is the success indicator in the hatching effort. Average percentage of fertility. hatchability. and embryo mortality from each group is shown in Table 3.

Variance analysis indicated that parent breeding group gave no significant effect towards the produced egg fertility $(\mathrm{P}>0.05)$. This result indicated that Naked-neck phenotype caused by
$\mathrm{Na}$ gene and Normal-feathered by na gene in both cock and hen were not giving any significant difference in the traits of the eggs fertility. Reciprocal breeding groups in LN and NL also showed no significant effect. This situation confirms that $\mathrm{Na}$ gene carried by cock parent and hen did not negatively affect the fertility of eggs produced.

The average percentage of the population fertility of all the breeding groups was $82.96 \%$. NL breeding groups showed the highest value, that was $3.42 \%$ higher than the average population of the breeding group. LN breeding group as the reciprocal breeding from NL was lower than breeding group of LL. NN and the average population of the breeding group. The high average percentage of egg fertility in the breeding group and the low average of fertility at the LN group need to be considered carefully, although statistically gave no significant result. Considering a change due to treatment of genetic influences a quantitative trait in cattle usually takes a long time and was followed by a selection of programs continuously from generation to generation in order to obtain significant changes in traits.

Similarly, the hatchability rate and embryo mortality during hatching of NL breeding groups showed an increment in the hatchability and decrement in embryo mortality than the average percentage of embryo hatching and mortality of the three other groups of breeding and the population average. Average hatchability rate was $5.87 \%$, in which higher and embryo mortality was $5.78 \%$ lower of the average of hatchability and embryo mortality rates from overall population.

Based on the observations on the embryo mortality that hatch at the end of period, it was found out the dead embryos with phenotype identified as Legund or Normal-feathered. In the first embryo candling (Candling I) on the $7^{\text {th }}$ day the embryo phenotype could not be identified yet. However, in the $16^{\text {th }}$ day of candling the number of embryos phenotype that have been identified were 98 chicks that consists of 60 chicks $(61 \%)$ with Legund phenotype and 38 chicks (39\%) were Normal-feathered. These results indicated that the embryo mortality with Legund phenotype were far higher than the embryo mortality of the Normal-feathered phenotype. Rahayu et al. (2001) stated that the death of the embryo with $\mathrm{Na}$ gene started at early hatching age and then continued to increase at the age of 15 days of hatching. The highest peak of the embryo's death 
was at the age of hatching up to the $18^{\text {th }}$ days of hatching until when they were hatched. The high rate of embryo's death with Legund phenotype was likely due to the influence of $\mathrm{Na}$ gene as explained by some experts as semi lethal (Sidadolog, 1991). The high rate of embryo's death with Legund phenotype indicates the influence of $\mathrm{Na}$ gene that was lethal to the individual with Nana genotype and lethal at $\mathrm{NaNa}$ genotype. Technically, a gene is said to be able to cause lethal premature death in animal that carry the gene. Gene that causes instantaneous death of cattle or a few times after birth is called semilethal. Some lethal genes showed co-dominant action. Some individual shows some of its lethal trait in heterozygote condition, while in a state homozygote, in which these individuals will die (Noor, 1996).

\section{CONCLUSION}

The spreading of the chick phenotype from the fourth parent breeding groups did not deviate from Mendel's law. Estimation of $\mathrm{Na}$ gene frequency in the Native Chicken population was 19.7\%. The $\mathrm{Na}$ gene within homozygote condition is lethal. Na gene gave no significant effects on egg fertility, hatchability and embryo mortality.

\section{REFERENCES}

Barua, A., M.A.R. Howlider and Y. Yoshimura. 1999. Indogenous Naked neck fowl of Bangladesh. World's Poult. Sci.. 54:279286.

Cahaner, A., N. Deeb and M. Gutman. 1993. Effects of the plumage reducing naked neck (Na) gene on the performance of fastgrowing broilers at normal and high ambient temperatures. Poult. Sci. 72:767775.

El-Safty, S. A, U.M. Ali and M.M. Fathi. 2006. Immunological parameters and laying performance of naked neck and normally feathered genotypes of chicken under winter condition of Egypt. Int. J. Poult. Sc. 5:780-785.

Galal, A., A.M.H. Ahmed, U.M. Ali and H.H. Younis. 2007. Influence of naked neck gene on laying performance and some hematological parameters of dwarfing hens. Int. J. Poult. Sci. 6: 807-813.
Gaspersz, V. 1991. Metode Perancangan Percobaan untuk Ilmu-ilmu Pertanian. Ilmu-ilmu Tehnik dan Biologi. Penerbit Armico. Bandung.

Horst, P. and P. K. Mathur. 1989. Position of Local fowl for tropical oriented breeding activities. In : MERAT. P. (Ed.). Genotype $\mathrm{x}$ Environment Interaction in Poultry. Jouyen-Josas: INRA. p.161-174.

Islam, M. A. and M. Nishibori. 2009. Indigenous naked neck chicken: a valuable genetic resource for Bangladesh. World's Poult. Sci. J. 65:125-138.

Islam, M. A. 2006. Comperative egg production and egg quality of indigenous full feathered and naked neck chicken at hot-humid climate. Bangladesh J. Anim. Sci. 35:99105.

Khatun, R., M., A Islam, S. Faruque, S.A. Azmal and M.S. Uddin. 2005. Study on the productive and reproductive performance of 3 native genotypes of chicken under intensive management. J. Bangladesh Agric. Univ. 3: 99-104.

Mazzi, C. M., J. F. Apareccido, M. I. F. Tiraboschi, V. J. M. Savino, A. A. D. Coelho and M. Macari. 2003. Polymorphism analysis of the hsp70 stress gene in broiler chickens (Gallus gallus) of different breeds. Gen. Mol. Biol.. 26(3):275 -281 .

Noor. R. R. 1996. Genetika Ternak. Penebar Swadaya. Jakarta.

Rahayu. B. W. I., J. H. P. Sidadolog dan M. Astuti. 2001. Kematian Ayam Legund (naked neck Fowl) Berdasarkan Genotip pada Fase Embrional. Mediagama III (2).

Sarwono, B. 2003. Beternak Ayam Buras. Penebar Swadaya. Jakarta.

Sidadolog, J. H. P. 1991. Pengaruh gen Na (Naked Neck) terhadap Pertumbuhan Ayam Kampung. Laporan Penelitian Fakultas Peternakan. Universitas Gadjah Mada. Yogyakarta.

Warnoto. 1993. Pengaruh gen $\mathrm{Na}$ (legund) terhadap Produksi dan Kualitas Daging Ayam Kampung. Program Pascasarjana Universitas Gadjah Mada. Yogyakarta. (Unpublished).

Warwick, E.J.. M. Astuti dan W. Hardjosubroto. 1987. Pemuliaan Ternak. Gadjah Mada Press. Yogyakarta. 